\title{
PENGEMBANGAN BAHAN AJAR MATEMATIKA EKONOMI BERBASIS LEARNING CYCLE BERBANTUAN SOFTWARE GEOGEBRA UNTUK MENINGKATKAN HASIL BELAJAR MAHASISWA
}

\author{
Sumarni $^{1)}$, Anggar Titis Prayitno ${ }^{2)}$, Mita Nurpalah ${ }^{3)}$ \\ Program Studi Pendidikan Matematika, Universitas Kuningan, Jawa Barat. \\ marni_39@yahoo.com \\ melodinejma@gmail.com
}

\begin{abstract}
This article examines the development of economic mathematics learning materials based on learning cycle assisted by GeoGebra software to improve student learning outcomes. The purpose of this study: 1) Obtaining the economic mathematics teaching materials developed in according with the principle of model learning cycle 5E; 2) Obtaining the developed economic mathematics material meets the valid and practical criteria; 3) Obtaining the mathematical materials of the developed mathematics economy can improve student learning outcomes. Stages or procedure research development that is requirement analysis; product development (teaching materials); expert validation and product revision; small-scale field trials. The results obtained in this study: 1) have developed economic mathematics learning materials based on learning cycle assisted GeoGebra software 2) Based on the validator's assessment, economic mathematics based on based learning cycle assisted GeoGebra software in good category with percentage of idealization of $77.96 \%$. 3) Based on field trials, teaching materials that are developed the economic mathematics learning materials based on learning cycle assisted GeoGebra software can improve student learning outcomes. Improved student learning outcomes using economic mathematics learning materials based on learning cycle assisted GeoGebra software is better than students who do not use economic mathematics learning materials based on learning cycle assisted GeoGebra software.
\end{abstract}

Keywords : Learning Outcomes, Learning Cycle, Economic Mathematics, Development of Teaching Materials, GeoGebra Software

\begin{tabular}{|l|}
\hline Abstrak \\
Artikel ini mengkaji pengembangan bahan ajar matematika ekonomi berbasis \\
learning cycle berbantuan software geogebra untuk meningkatkan hasil belajar \\
mahasiswa. Tujuan penelitian ini adalah sebagai berikut: 1) Mempreoleh bahan ajar \\
matematika ekonomi yang dikembangkan sesuai dengan prinsip model \\
pembelajaran learning cycle 5E; 2) Memperoleh bahan ajar matematika ekonomi \\
yang dikembangkan memenuhi kriteria valid dan praktis; 3) Memperoleh bahan ajar \\
matematika ekonomi yang dikembangkan dapat meningkatkan hasil belajar \\
mahasiswa. Tahapan atau prosedur penelitian pengembangan yaitu analisis \\
kebutuhan; pengembangan produk (bahan ajar); validasi ahli dan revisi produk; uji \\
Coba lapangan skala kecil. Hasil yang diperoleh dalam penelitian ini adalah 1) telah \\
dikembangkan bahan ajar matematika ekonomi berbasis learning cycle berbantuan \\
\hline
\end{tabular}


software GeoGebra 2) Berdasarkan penilaian validator, bahan ajar matematika ekonomi berbasis learning cycle berbantuan software GeoGebra dalam kategori baik dengan presentase keidealan 77,96 \%. 3) Berdasarkan uji coba lapangan, bahan ajar yang dikembangkan yaitu bahan ajar matematika ekonomi berbasis learning cycle berbantuan GeoGebra dapat meningkatkan hasil belajar mahasiswa.Peningkatan hasil belajar mahasiswa yang menggunakan bahan ajar matematika ekonomi berbasis learning cycle berbantuan GeoGebra lebih baik dibandingkan mahasiswa yang pembelajarannya tidak menggunakan bahan ajar matematika ekonomi berbasis learning cycle berbantuan GeoGebra

Kata Kunci: Hasil Belajar, Learning Cycle, Matematika Ekonomi, Pengembangan Bahan Ajar, Software GeoGebra

\section{PENDAHULUAN}

Matematika sebagai salah satu mata pelajaran wajib dalam kurikulum pendidikan di Indonesia, dipelajari pada pendidikan dasar, menengah hingga pendidikan tinggi. Matematika sebagai ratu dan pelayan ilmu, mempunyai peran yang sangat penting dalam perkembangan ilmu pengetahuan dan teknologi. Banyak ilmu-ilmu yang penemuan dan perkembangannya menggunakan matematika, salah satunya adalah Teori Ekonomi mengenai Permintaan dan Penawaran dikembangkan melalui konsep Fungsi Kalkulus tentang Diferensial dan Integral.

\begin{tabular}{llr}
\multicolumn{2}{c}{ Berdasarkan hakikat } \\
matematika sebagai ratu & ilmu \\
pengetahuan, & matematika & selain
\end{tabular} tumbuh dan berkembang untuk dirinya sendiri juga untuk melayani kebutuhan ilmu pengetahuan lainnya dalam pengembangan dan operasinya. Cabang matematika yang memenuhi fungsinya untuk melayani kebutuhan ilmu pengetahuan lain dalam pengembangan dan operasinya dinamakan dengan matematika Terapan (Applied Mathematic). Salah satu cabang matematika terapan adalah matematika ekonomi. Matematika ekonomi dalam pengembangannya banyak menggunakan konsep matematika, diantaranya konsep fungsi linier, fungsi non linier, diferensial, integral, logaritma, barisan, eksponen dan konsep lainnya yang digunakan dalam pengembangan matematika ekonomi, Perkembangan ilmu pengetahuan dan teknologi yang semakin pesat, menuntut manusia untuk terus belajar agar tidak tertinggal dalam perkembangan ilmu pengetahuan dan teknologi. Salah satu ilmu pengetahuan yang harus dipelajari pada pendidikan tinggi adalah matematika ekonomi. Seperti yang telah diapaparkan sebelumnya bahwa matematika ekonomi merupakan salah satu ilmu matematika terapan, yang dalam pengembangannya banyak menggunakan konsep matematika. Sehingga ketika mempelajari mata kuliah matematika ekonomi mahasiswa harus memahami dan menguasai konsep matematika yang digunakan dalam mempelajari materi matematika ekonomi.

Pembelajaran matematika ekonomi hendaknya diarahkan kepada pemahaman konsep dan ide matematika yang diperlukan untuk menyelesaikan masalah ekonomi. Namun pada kenyataannya sebagian besar mahasiswa menganggap 
matematika adalah mata pelajaran yang sulit, sehingga mereka tidak suka dan malas untuk belajar matematika. Siswa merasa pusing dengan perhitungan dan rumus-rumus matematika yang mereka pelajari. mahasiswa cenderung mengahafal rumus-rumus yang diberikan, tetapi mereka terkadang bingung menggunakan rumus yang mana, untuk meyelesaikan suatu soal, kadang mereka juga lupa dengan rumus-rumus yang mereka hafalkan dan akhirnya terjadi kesalahan penggunaan rumus dalam menyelesaikan soal. Hal tersebut menjadi salah satu faktor yang menyebabkan rendahnya hasil belajar matematika ekonomi.

Setiap proses belajar yang dilaksanakan oleh peserta didik akan menghasilkan hasil belajar. Hasil belajar merupakan salah satu indikator untuk melihat tujuan dari suatu pembelajaran tercapai atau tidak. untuk dapat mencapai hasil belajar yang baik, peserta didik harus bisa mengoptimalkan kemampuan didalam setiap proses pembelajaran dengan baik pula. Dalam proses pembelajaran, dosen mempunyai peranan dan tanggung jawab yang besar sebagai pengajar sekaligus pendidik, dalam rangka membantu meningkatkan keberhasilan hasil belajar mahasiswa. Salah satu cara untuk membantu meningkatkan keberhassilan mahasiswa adalah melalui penyediaan bahan ajar yang memfasilitiasi mahasiswa dalam proses pembelajaran.

Selama ini bahan ajar yang digunakan dalam pembelajaran matematika ekonomi berupa buku teks, namun penggunaan buku teks kurang memfasilitasi mahasiswa dalam proses pembelajaran. Konten materi dan penyajian materi pada buku teks kurang memfasilitasi mahasiswa untuk mengkonstruksi pemahaman terhadap konsep matematika yang diterapkan dalam pembelajaran matematika ekonomi, sehingga mahasiswa mengalami kesulitan dalam memahami materi yang dipelajari. Dalam penyusunan bahan aja yang memfasilitasi mahasiswa untuk belajar secara bermakna melalui proses mengkonstruksi konsep dapat menggunakan prinsip langkah-langkah dalam model Learning Cycle (LC). LC merupakan salah satu model pembelajaran konstruktivisme yang dalam proses pembelajarannya membekali peserta didik dengan konsep atau pemahaman baru secara mendalam. Selain itu, LC berlandaskan pada pendekatan konstruktivisme, yang memasukkan keterampilan berpikir tingkat tinggi, merangsang mahasiswa untuk melakukan eksplorasi, menemukan dan memperoleh pengalaman. LC juga memfasilitasi proses pembelajaran dan memberikan kesempatan kepada mahasiswa untuk belajar secara bermakna (Lorsbach, 2002).

Melalui pembelajaran LC pembelajaran yang dilakukan oleh dosen lebih bermakna bagi mahasiswa. LC sangat sesuai dengan standar proses pembelajaran yang diamanatkan oleh Kurikulum Nasional Indonesia, digunakan dalam pembelajaran yaitu pembelajaran berbasis saintifik.

\section{Pemanfaatan}

software matematika dalam pembuatan bahan ajar, terutama dalam pembuatan bahan ajar matematika ekonomi yang dalam konten dan tampilan bahan ajar tersebut menampilkan grafik - grafik. Salah satu software yang memfasilitasi dan dapat membantu dalam pembuatan grafik - grafik adalah software GeoGebra. Software GeoGebra dapat memfasilitasi dan 
membantu dalam pembuatan grafik fungsi ekonomi, seperti grafik fungsi permintaan, grafik fungsi penawaran, grafik titik keseimbangan, grafik fungsi subsidi dan pajak. Software GeoGebra dapat membantu memudahkan dalam pembuatan grafik-grafik tersebut.

Berdasarkan permasalahan di atas, penulis melakukan penelitian dengan pengembangan bahan ajar matematika ekonomi berbasis learning cycle berbantuan software geogebra untuk meningkatkan hasil belajar mahasiswa. Tujuan penelitian ini adalah sebagai berikut: 1) Mempreoleh bahan ajar matematika ekonomi yang dikembangkan sesuai dengan prinsip model pembelajaran learning cycle 5E; 2) Memperoleh bahan ajar matematika ekonomi yang dikembangkan memenuhi kriteria valid dan praktis; 3) Memperoleh bahan ajar matematika ekonomi yang dikembangkan dapat meningkatkan hasil belajar mahasiswa.

\section{KAJIAN TEORI}

\section{Bahan Ajar Matematika Ekonomi}

Bahan ajar adalah seperangkat materi yang disusun secara sistematis baik tertulis maupun tidak, sehingga tercipta lingkungan/suasan yang memungkinkan peserta didik untuk belajar. Bentuk bahan ajar dapat berupa bahan cetak seperti :hand out, buku, modul, lembar kerja siswa, brosur, leaflet, dan wallchart. Bahan ajar juga dapat berbentuk audio visual seperti: video/film, VCD, dapat juga berbentuk Audio seperti: radio, kaset, CD audio. Terdapat juga bahan ajar dalam bentuk visual: seperti foto, gambar, model/maket dan bahan ajar berbentuk multi media: seperti CD interaktif, computer based, dan internet.

\begin{tabular}{lrrr}
\multicolumn{3}{c}{ Matematika } & ekonomi \\
merupakan & ilmu yang & digunakan \\
sebagai & pendekatan & dalam
\end{tabular}
mempelajari analisis ekonomi. Ahli ekonomi menggunakan simbol-simbol matematis untuk menyatakan permasalahan ekonomi serta menggunakan dalil-dalil matematis untuk membantu pembahasan masalah tersebut.

Berdasarkan pemaparan di atas, bahan ajar matematika ekonomi yang dikembangkan adalah seperangkat materi matematika ekonomi yang disusun secara sistematis secara tertulis dalam bentuk modul, yang dikembangkan berdasar prinsip model Learning Cycle $5 E$ dan dalam pembuatan tampilan grafik fungsi ekonomi dibantu menggunakan software GeoGebra.

\section{Learning Cycle 5E}

Model pembelajaran LC 5E adalah model pembelajaran yang berpusat pada peserta didik. Model pembelajaran LC 5E, model pembelajaran yang memberikan kesempatan kepada mahasiswa untuk mengoptimalkan hasil belajar mahasiswa dalam proses pembelajaran. Model pembelajaran LC 5E terdapat tahap-tahap kegiatan (tahap) yang diorganisasikan sedemikian rupa, sehingga mahasiswa dapat mencapai kompetensikompetensi yang menjadi tujuan pembelajaran.

Beberapa penelitian dalam bidang sains mengemukakan bahwa learning cycle efektif untuk meningkatkan penguasaan bahan pelajaran, mengembangkan penalaran ilmiah dan pengembangan ketertarikan dan sikap postitf terhadap sains (Madu \& Amaechi, 2012). Meskipun LC 5E dikembangkan BSCS untuk meningkatkan pendidikan sains, tetapi 
LC 5E telah diadaptasi dan digunakan untuk meningkatkan pembelajaran pada bidang lain, seperti pendidikan teknologi dan pendidikan matematika. Hasil penelitian Pulat (Bybee at al., 2006) mengenai 'Pengaruh LC 5E terhadap hasil belajar matematika dan sikap terhadap matematika pada siswa kelas 6', menunjukkan bahwa hasil belajar matematika siswa meningkat setelah belajar menggunakan LC 5E. Secara signifikan berpengaruh pada pengetahuan konsep dan prosedural dan meningkatkan sikap siswa terhadap matematika.

Proses pembelajaran

menggunakan LC 5E dosen berperan sebagai motivator dan fasilitator yang mengelola tahapan kegiatan pembelajaran, dimulai dari perencanaan pembelajaran (terutama perangkat pembelajaran), pelaksanaan pembelajaran (terutama pemberian pertanyaan-pertanyaan arahan dan proses bimbingan) dan evaluasi. LC 5E terdiri atas lima tahap yaitu (a) pembangkit minat (engagement), (b) eksplorasi (exploration), penjelasan (explanation), (d) elaborasi (elaboration), dan (e) evaluasi (evaluation) (Lorsbach, 2002; Bybee et al, 2006; Madu \& Amaechi, 2012; Ergin, 2012). Pemaparan tahap-tahap yang terdapat pada LC 5E, yaitu sebagai berikut: (1) Tahap engagement, bertujuan mempersiapkan diri mahasiswa, dengan cara menggali minat dan rasa ingin tahu mahasiswa tentang pokok bahasan matematika ekonomi yang akan diajarkan. Menggali minat dan rasa ingin tahu mahasiswa dengan mengaitkan materi yang telah dimiliki mahasiswa; (2) Tahap exploration, mahasiswa diberi kesempatan untuk bekerja sama dalam kelompokkelompok kecil agar terjadi tukar pikiran antar mahasiswa; (3) Tahap explanation, dosen mendorong mahasiswa untuk menjelaskan ide yang telah mereka dapatkan, lalu diwujudkan dalam presentasi kelompok; (4) Tahap elaboration, mahasiswa dapat mengaplikasikan ide serta gagasannya ke dalam menyelesaikan latihan soal; (5) Tahap evaluation, dilakukan evaluasi pada mahasiswa dengan mengoreksi hasil pekerjaan mahasiswa dan menyimpulkan pelajaran yang telah diberikan (Lorsbach, 2002).

\section{Hasil Belajar}

Hasil belajar merupakan output dalam suatu kegiatan belajar mengajar. Menurut Suprijono (2013) "hasil belajar adalah pola-pola perbuatan, nilai-nilai, pengertianpengertian, sikap-sikap, apresiasi dan keterampilan". Sedangkan menurut Sudjana (2009) mengemukakan bahwa: hasil belajar adalah kemampuan-kemampuan yang dimiliki siswa setelah ia menerima pengalaman belajarnya. Menurut Hamalik (2010), mengemukakan bahwa: "hasil belajar menunjukkan kepada prestasi belajar, sedangkan prestasi belajar itu merupakan indikator adanya derajat perubahan tingkah laku siswa". Hal tersebut menunjukkan bahwa untuk dapat mencapai hasil belajar yang baik, mahasiswa harus bisa mengoptimalkan kemampuan didalam setiap proses pembelajaran dengan baik pula.

Setiap proses belajar yang dilaksanakan oleh peserta didik akan menghasilkan hasil belajar. Dalam proses pembelajaran, dosen mempunyai peranan dan tanggung jawab yang besar sebagai pengajar sekaligus pendidik, dalam rangka membantu meningkatkan keberhasilan peserta didik. 
Dimyati dan Mudjiono (2009) mengemukakan bahwa: hasil belajar adalah hasil yang ditunjukkan dari suatu interaksi tindak belajar dan biasanya ditunjukkan dengan nilai tes yang diberikan pendidik.

Berdasarkan beberapa pendapat di atas, maka dapat disimpulkan bahwa hasil belajar adalah kemampuan-kemampuan yang diperoleh mahasiswa setelah mengikuti proses pembelajaran yang ditunjukkan dengan nilai tes yang diberikan oleh dosen.

Mengukur kemampuan hasil belajar diperlukan beberapa indikator. Adapun indikator hasil belajar yang dikemukakan oleh Kingsley ( Sudjana 2009) secara umum indikator hasil belajar meliputi; (a) keterampilan dan kebiasaan, (b) pengetahuan dan pengertian, (c) sikap dan cita-cita. Sedangkan menurut Benyamin Bloom (Sudjana 2009) mengemukakan bahwa: hasil belajar terbagi menjadi tiga ranah yaitu :

a. Ranah kognitif berkenaan dengan hasil belajar intelektual yang terdiri dari enam aspek, yakni pengetahuan atau ingatan, pemahaman, aplikasi, analisis, sintesis, dan evaluasi. Kedua aspek pertama disebut kognitif tingkat rendah dan keempat aspek berikutnya termasuk kognitif tingkat tinggi.

b. Ranah afektif berkenaan dengan sikap yang terdiri dari lima aspek, yakni penerimaan, jawaban atau reaksi, penilaian, organisasi, dan internalisasi.

c. Ranah psikomotoris berkenaan dengan hasil belajar keterampilan dan kemampuan bertindak (gerakan refleks, keterampilan gerakan dasar, kemampuan perseptual, keharmonisan atau ketepatan, gerakan keterampilan kompleks, dan gerakan ekspresif dan interpretatif).

Ketiga ranah tersebut menjadi objek penilaian hasil belajar. Diantara ketiga ranah itu, ranah kognitiflah yang paling banyak dinilai oleh para dosen di sekolah karena berkaitan dengan kemampuan para siswa dalam menguasai isi bahan pengajaran. Sedangkan ranah afektik dan psikomotor ada yang tampak pada saat proses belajar mengajar berlangsung dan ada pula yang baru tampak kemudian (setelah pengajaran diberikan) dalam praktek kehidupannya di lingkungan keluarga, sekolah, dan masyarakat. Hasil belajar afektif dan psikomotoris sifatnya lebih luas, lebih sulit dipantau namun memiliki nilai yang sangat berarti bagi kehidupan siswa sebab dapat secara langsung mempengaruhinya.

\section{METODE PENELITIAN}

Desain yang digunakan dalam penelitian ini adalah Research and Development. Penelitian ini berfokus pada pengembangan bahan ajar matematika ekonomi dengan pendekatan model learning cycle $5 E$ dan pengembangan instrument untuk mengukur hasil belajar mahasiswa. Tahapan atau prosedur penelitian pengembangan ini mengacu pada lima langkah utama yang dikemukakan oleh Tim Puslitjaknov (Hajizah, 2014), yaitu analisis kebutuhan; pengembangan produk (bahan ajar); validasi ahli dan revisi produk; uji Coba lapangan skala kecil; dan uji coba lapangan skala besar. Akan tetapi karena keterbatasan waktu uji coba lapangan skala besar tidak dapat dilakukan.

Bahan ajar yang dikembangkan dalam penelitian ini yaitu bentuk paper-based. Paper-based merupakan outline (modul) pertama dari materi 
ajar yang sesuai dengan materi matematika ekonomi. Hasil outline (modul) ini divalidasi oleh pakar matematika ekonomi dan kemudian digunakan sebagai bahan ajar dalam pembelajaran matematika ekonomi.

Selama proses validasi bahan ajar, alat pengumpul data yang digunakan adalah lembar validasi kepada pakar. Semua data yang terkumpul dari proses validasi akan dianalisis secara deskriptif kualitatif. Hasil analisis dokumen lembar validasi digunakan sebagai bahan acuan untuk merevisi hingga diperoleh bahan ajar bahan ajar matematika ekonomi dengan pendekatan model Learning Cycle berbantuan Software GeoGebra yang memenuhi kriteria valid.

Untuk mengukur hasil belajar belajar mahasiswa disusun instrument tes sesuai dengan indikator hasil belajar. Selain itu adanya lembar observasi yang digunakan sebagai data pendukung dalam menganalisis data. Semua data yang terkumpul dari hasil penelitian akan dianalisis secara dekskriptif kualitatif.

\section{HASIL PENELITIAN \\ PEMBAHASAN \\ Hasil Penelitian}

\section{Tahap Analisis}

Pada tahap ini dilakukan analisis terhadap kurikulum, kebutuhan mahasiswa, kebutuhan dosen dan analisis media/sumber belajar. Berdasarkan hasil pengamatan awal dilakukan dengan menganalisis kebutuhan mahasiswa penelti memperoleh informasi sebagai berikut: 1) mahasiswa masih terbiasa belajar secara pasif, hal ini terjadi karena selama pembelajaran berlangsung, dosen lebih banyak mengajar di depan kelas, menulis dan menjelaskan materi menggunakan metode ceramah dan pemberian contoh-contoh soal, sementara itu mahasiswa hanya mencatat materi yang dosen tulis di papan tulis, akibatnya mahasiswa cenderung pasif dalam mengikuti proses pembelajaran; 2) pembelajaran tidak didukung dengan perangkat pembelajaran yang memadai. Umumnya mahasiswa tidak memiliki buku pegangan sebagai sumber belajar, mahasiswa hanya mengandalkan materi yang diberikan oleh dosen pada saat proses pembelajaran. Sehingga mahasiswa tidak memiliki gambaran tentang materi yang akan dipelajari sebelum proses pembelajaran berlangsung. 3) nilai mahasiswa pada mata kuliah Matematika Ekonomi masih tergolong rendah, dikarenakan mahasiswa masih mengalami kesulitan dalam memahami konsep Matematika yang menjadi dasar untuk menyelesaikan permasalahan dalam Ekonomi.

\section{Tahap Pengembangan}

Pada tahap ini dikembangkan bahan ajar Matematika Ekonomi Berbasis Learning Cycle Berbantuan Software GeoGebra untuk Meningkatkan Hasil Belajar Mahasiswa. Bahan ajar yang dikembangkan berupa modul untuk membimbing dan mengarahkan mahasiswa dalam mengkonstruksi konsep Matematika Ekonomi berbasis Learning Cycle berbantuan Software GeoGebra. Struktur bahan ajar yang dikembangkan dapat dilihat pada tabel 1 berikut ini. 


\section{Tabel 1}

Struktur Bahan Ajar Matematika Ekonomi Berbasis Learning Cycle Berbantuan Software GeoGebra

\begin{tabular}{|l|l|l|}
\hline No & \multicolumn{1}{|c|}{ Bagian } & \multicolumn{1}{c|}{ Isi } \\
\hline 1 & Cover & $\begin{array}{l}\text { Judul modul/bahan ajar, penyusun, logo instansi, } \\
\text { nama instansi }\end{array}$ \\
\hline 2 & Kata Pengantar & $\begin{array}{l}\text { Ucapan syukur, tujuan penyusunan bahan ajar, } \\
\text { ucapan terima kasih dan harapan manfaat dari } \\
\text { bahan ajar }\end{array}$ \\
\hline 3 & Daftar isi & Konten yang terdapat dalam bahan ajar \\
\hline 4 & Tujuan pembelajaran & Pemaparan Tujuan pembelajaran \\
\hline 5 & $\begin{array}{l}\text { Pendahuluan / pengenalan } \\
\text { software GeoGebra }\end{array}$ & $\begin{array}{l}\text { Pengenalan software GeoGebra, penjelasan } \\
\text { manfaat software GeoGebra dan praktik menu } \\
\text { dan tool GeoGebra dalam pembelajaran } \\
\text { matematika ekonomi dan praktik materi fungsi } \\
\text { linear menggunakan GeoGebra }\end{array}$ \\
\hline 6 & $\begin{array}{l}\text { Konsep Fungsi Liniear } \\
\text { dalam Matematika } \\
\text { (Engagement) }\end{array}$ & $\begin{array}{l}\text { Pengertian fungsi linear, pembentukan } \\
\text { persamaan liniear, hubungan dua garis lurus. }\end{array}$ \\
\hline 7 & $\begin{array}{l}\text { Penerapan fungsi liniear } \\
\text { dalam matematika } \\
\text { ekonomi (exploration } \\
\text { menggunakan GeoGebra) }\end{array}$ & $\begin{array}{l}\text { Fungsi permintaan, Fungsi penawaran, } \\
\text { Keseimbangan pasar, Pengaruh pajak terhadap } \\
\text { keseimbangan pasar, Pengaruh subsidi terhadap } \\
\text { keseimbangan pasar, Fungsi biaya, Fungsi } \\
\text { penerimaan dan analisis peluang pokok }\end{array}$ \\
\hline 7 & Daftar Pustaka & Sumber rujukan dalam menyusun bahan ajar \\
\hline
\end{tabular}

Selain pengembangan bahan ajar Matematika Ekonomi berbantuan GeoGebra, dalam penelitian ini juga dikembangkan instrumen tes hasil belajar mahasiswa. Indikator hasil belajar ranah kognitif berdasarkan taksonomi Bloom sebagai berikut (1) Pengetahuan; ( 2) Pemahaman; (3) Aplikasi; (4) Sintesis;

Mengevaluasi dan (6) Mengkreasi. Dan dikembangkan juga lembar observasi aktivitas mahasiswa dalam pembelajaran Matematika Ekonomi sebagai instrumen untuk hasil belajar ranah afektif dan psikomotor.

Berikut adalah hasil pengembangan instrument penelitian (draft bahan ajar, instrumen tes hasil belajar, dan lembar observasi aktivitas pembelajaran mahasiswa) yang telah diperoleh pada tahap ini.

\section{a. Hasil Validasi dan Revisi Instrumen Penelitian}

Instrument penelitian yang dikembangkan adalah (1) draft bahan ajar, (2) instrumen tes hasil belajar, dan (3) lembar observasi aktivitas pembelajaran mahasiswa dinilai oleh tiga orang validator yang berkompeten untuk menilai kelayakan instrument penelitian.

Berdasarkan validator, nilai rata-rata validasi kualitas bahan ajar yang dikembangkan termasuk pada kategori baik. Berdasarkan indikator validasi bahan ajar maka bahan ajar yang dikembangkan dikatakan valid. Sehingga bahan ajar yang dikembangkan dapat diuji coba di lapangan. Rekapitulasi nilai validasi 
bahan ajar oleh validator disajikan pada tabel berikut.

Tabel 2

Rekapitulasi Nilai Validasi Bahan Ajar oleh Validator

\begin{tabular}{|c|l|c|c|c|c|c|c|}
\hline \multirow{2}{*}{ No } & \multirow{2}{*}{$\begin{array}{l}\text { Komponen } \\
\text { Bahan Ajar }\end{array}$} & \multicolumn{3}{|c|}{ Validator } & Jumlah & Prosentase & Krieteia \\
\cline { 2 - 8 } & $\begin{array}{l}\text { Komponen } \\
\text { Kelakayakan Isi }\end{array}$ & 40 & 42 & 39 & 141 & 78,33 & Baik \\
\hline 2 & $\begin{array}{l}\text { Komponen } \\
\text { Kebahasaan }\end{array}$ & 60 & 60 & 59 & 142 & 78,88 & Baik \\
\hline 3 & $\begin{array}{l}\text { Komponen } \\
\text { Penyajian }\end{array}$ & 40 & 40 & 41 & 138 & 76,66 & Baik \\
\hline \multicolumn{7}{|c|}{ Rata-rata } \\
\hline
\end{tabular}

Beberapa revisi yang dilakukan terhadap bahan ajar, instrumen tes hasil belajar dan lembar observasi aktivitas belajar mahasiswa dijabarkan sebagai berikut:

1) Bahan Ajar
Substansi yang direvisi meliputi komponen kelayakan isi, komponen kebahasaan dan komponen penyajian. penjelasan lebih lengkap tentang revisi yang dilakukan terhadap bahan ajar dapat dilihat pada Tabel 3 berikut.

Tabel 3

Revisi Bahan Ajar Berdasarkan Masukan Validator

\begin{tabular}{|l|l|l|}
\hline No. & \multicolumn{1}{|c|}{ Sebelum direvisi } & \multicolumn{1}{c|}{ Setelah direvisi } \\
\hline 1. & $\begin{array}{l}\text { Masih terdapat kesalahan dalam } \\
\text { pengetikan. }\end{array}$ & $\begin{array}{l}\text { Kesalahan pengetikan sudah } \\
\text { diperbaik }\end{array}$ \\
\hline 2. & $\begin{array}{l}\text { Konsep materi fungsi linear, } \\
\text { masih kurang lengkap. }\end{array}$ & $\begin{array}{l}\text { Konsep materi fungsi linear, di } \\
\text { lengkapi dengan mengambil } \\
\text { materi dari sumber (buku). }\end{array}$ \\
\hline 3. & $\begin{array}{l}\text { Belum disertai perintah/petunjuk } \\
\text { untuk explorasi menggunakan } \\
\text { GeoGebra }\end{array}$ & $\begin{array}{l}\text { Sudah ada perintah/petunjuk } \\
\text { untuk explorasi menggunakan } \\
\text { GeoGebra }\end{array}$ \\
\hline
\end{tabular}

2) Instrumen Tes Hasil Belajar

Penilaian validator terhadap instrumen tes hasil belajar didasarkan pada kisi-kisi hasil belajar yang termuat dalam lembar validasi instrumen tes belajar. Pada umumnya hasil penilaian validator menyatakan instrumen hasil belajar baik dan dapat digunakan dengan sedikit revisi. Validator memberikan masukan untuk memperbaiki redaksi kalimat dan menyarankan

untuk mempertimbangkan banyaknya soal dengan waktu, lebih baik dikurangi. Berdasarkan kesimpulan dan masukan validator, selanjutnya dilakukan revisi terhadap instrumen tes hasil belajar sesuai saran dan masukan dari validator.
3) Lembar
Observasi Aktivitas Belajar 
Penilaian validator terhadap lembar observasi aktivitas belajar didasarkan pada indikator-indikator yang termuat dalam validasi lembar observasi aktivitas belajar. Pada umumnya hasil penilaian validator menyatakan lembar obseervasi aktivitas belajar baik dan dapat digunakan dengan sedikit revisi. Validator memberikan masukan untuk memperbaiki redaksi kalimat dan membuat lembar aktivitas untuk dosen juga. Berdasarkan kesimpulan dan masukan validator, selanjutnya dilakukan revisi terhadap lembar observasi aktivitas belajar dan dikembangkan juga lembar aktivitas untuk dosen.

\section{Tahap Uji Coba untuk Pematangan Bahan Ajar \\ 1) Deskripsi Peningkatan Skor Pretes dan Postes}

Berdasarkan hasil uji coba bahan ajar yang telah dikembangkan dalam skala kecil dianalisis dengan melihat peningkatan hasil belajar mahasiswa menggunakan uji gain ternormalisasi berdasarkan hasil pretes dan postes mahasiswa. Berikut ini merupakan deskripsi data hasil belajar mahasiswa sebelum dan sesudah pembelajaran menggunakan bahan ajar matematika ekonomi berbasis learning cycle berbantuan GeoGebra

Tabel 4

Statistik Deskriptif Hasil Tes Hasil Belajar Mahasiswa Kelas Eksperimen

\begin{tabular}{|c|c|c|c|c|c|}
\hline \multirow{2}{*}{$\begin{array}{c}\text { Tes Hasil } \\
\text { Belajar }\end{array}$} & \multirow{2}{*}{ Skor Ideal } & \multicolumn{5}{|c|}{ Postes } \\
\cline { 3 - 6 } & & $\bar{x}$ & SD & $\boldsymbol{x}_{\text {min }}$ & $\boldsymbol{x}_{\text {maks }}$ \\
\hline Sebelum & 100 & 5 & 5 & 5 & 5 \\
\hline Sesudah & 100 & 69,88 & 1,070 & 50 & 95 \\
\hline
\end{tabular}

Tabel 5

Statistik Deskriptif Hasil Tes Hasil Belajar Mahasiswa Kelas Kontrol

\begin{tabular}{|c|c|c|c|c|c|}
\hline \multirow{2}{*}{$\begin{array}{c}\text { Tes Hasil } \\
\text { Belajar }\end{array}$} & \multirow{2}{*}{ Skor Ideal } & \multicolumn{5}{|c|}{ Postes } \\
\cline { 3 - 6 } & & $\bar{x}$ & SD & $\boldsymbol{x}_{\text {min }}$ & $\boldsymbol{x}_{\text {maks }}$ \\
\hline Sebelum & 100 & 5 & 5 & 5 & 5 \\
\hline Sesudah & 100 & 63,59 & 1,186 & 40 & 90 \\
\hline
\end{tabular}

Berdasarkan deskripsi di atas, dapat dilihat bahwa rerata hasil belajar mahasiswa siswa secara keseluruhan, sebelum pembelajaran dan sesudah pembelajaran mengalami peningkatan. Akan tetapi, untuk melihat peningkatan hasil belajar mahasiswa dilakukan uji peningkatan mengggunakan uji Normalitas Gain (g), rumus yang digunakan adalah sebagai berikut.

$$
g=\frac{S_{\text {pos }}-S_{\text {pre }}}{S M I-S_{\text {pre }}}
$$

Hasil perolehan Normalitas Gain

(g) skor hasil belajar mahasiswa secara umum dapat dilihat pada tabel berikut 
Tabel. 6

Hasil Peningkatan Skor Hasil Belajar Mahasiswa Kelas Eksperimen

\begin{tabular}{|c|c|c|}
\hline Kriteria & Jumlah Mahasiswa & Persentasse \\
\hline Rendah & 0 & $0 \%$ \\
\hline Sedang & 16 & $50 \%$ \\
\hline Tinggi & 16 & $50 \%$ \\
\hline
\end{tabular}

Berdasarkan tabel terlihat bahwa hasil peningkatan hasil belajar mahasiswa setelah menggunakan bahan ajar matematika ekonomi berbasis learning cycle berbantuan GeoGebra dengan kriteria peningkatan sedang sebanyak $50 \%$, dan tinggi sebanyak $50 \%$. Rata-rata klasikal skor Normalitas Gain $(g)$ dapat ditentukan berdasarkan rata-rata skor hasil belajar mahasiswa yang diukur berdasarkan skor hasil belajar mahasiswa sebelum dan sesudah pembelajaran menggunakan bahan ajar matematika ekonomi berbasis learning cycle berbantuan GeoGebra diperoleh data sebagai berikut.

- Rata - rata skor hasil belajar sebelum pembelajaran (pretes) $=5$

- Rata - rata skor hasil belajar setelah pembelajaran $($ postes $)=68,88$

- $\quad$ Nilai maksimal $=100$

- Maka rata-rata klasikal skor normalitas gain $(\mathrm{g})$ adalah:

$$
g=\frac{S_{\text {pos }}-S_{\text {pre }}}{S M I-S_{\text {pre }}}
$$

$$
\begin{gathered}
g=\frac{68,88-5}{100-5} \\
g=0,67
\end{gathered}
$$

Jadi secara rata-rata klasikal diperoleh nilai Normalitas gain $(\mathrm{g})$ sebesar 0,67 yang berarti tafsiran peningkatan hasil belajar termasuk dalam kategori sedang.

2) Uji Beda Skor Postes Hasil Belajar Kelas Kontrol dan Kelas Eksperimen

Uji beda skor postes kelas eksperimen dan kelas kontrol digunakan untuk mengetahui perbedaan hasil belajar mahasiswa yang belajar menggunakan bahan ajar yang dikembangkan dan hasil belajar mahasiswa yang tidak belajar menggunakan bahan ajar matematika ekonomi berbasis learning cycle berbantuan GeoGebra. Uji perbedaan rataan hasil psotes kelas eksperimen dan kelas kontrol dengan menggunakan Mean-Whitney $U$ dengan bantuan program SPSS 16 for Windows.

Adapun rumusan hipotesisnya adalah sebagai berikut.

$H_{0}: \eta_{1}=\eta_{2}$, Tidak terdapat perbedaan skor hasil belajar kelas kontrol dan kelas eksperimen secara signifikan.

$\mathrm{H}_{\mathrm{a}}: \eta_{1} \neq \eta_{2}, \quad$ Terdapat perbedaan skor hasil belajar kelas kontrol dan kelas eksperimen secara signifikan.

Berikut rangkuman hasil uji perbedaan rataan skor hasil belajar. 
Tabel. 7

Uji Perbedaan Rataan Skor Postes Hasil Belajar

\begin{tabular}{|c|c|c|c|}
\hline \multicolumn{3}{|c|}{ Statistik } & \multirow{2}{*}{ Keterangan } \\
\hline Mann-Whitney U & Z & Asymp. Sig. (2-tailed) & \\
\hline 345,000 & $-2,252$ & 0,024 & \multirow{2}{*}{$\mathrm{H}_{\mathrm{o}}$ Ditolak } \\
\hline
\end{tabular}

Dari hasil uji Mann-Whitney $U$ di atas, diperoleh nilai $p$-value atau Sig. (2-tailed) yaitu $0,024<\alpha(\alpha=$ 0,05). Hal ini menunjukkan bahwa $\mathrm{H}_{\mathrm{o}}$ ditolak, artinya terdapat perbedaan yang signifikan antara skor postes hasil belajar mahasiswa kelas kontrol dan kelas eksperimen secara signifikan. Sehingga, terdapat perbedaan yang signifikan antara skor postes hasil belajar mahasiswa menggunakan bahan ajar matematika ekonomi berbasis learning cycle berbantuan GeoGebra dan yang tidak menggunakan bahan ajar matematika ekonomi berbasis learning cycle berbantuan GeoGebra.

\section{3) Hasil Lembar Observasi}

Observasi dilakukan untuk mengumpulkan data mengenai aktivitas pembelajaran yaitu aktivitass dosen dan mahasiswa selama proses pembelajaran melalui LC 5E dengan menggunakan bahan ajar yang telah dkembangkan. Observasi hanya dilakukan pada kelas sebanyak 6 kali pertemuan. Pada setiap pertemuan peneliti dibantu rekan dosen yang bertindak sebagai observer. Hasil pengamatan yang dilakukan dalam penelitian ini meliputi aktivitas dosen dan mahasiswa yang menggunakan bahan ajar yang dikembangkan. Aktivitas dosen dan mahasiswa dalam pembelajaran LC 5E diperoleh melalui pengamatann yang dilakukan oleh observer pada setiap pertemuan. Persentase aktivitas dosen dari pertemuan ke-1 sampai pertemuan ke6 relatif semakin lebih baik, meskipun terdapat penurunan pada pertemuan ke-6. Rerata persentase berturut-turut adalah 72,94\%, 72,94\%, 74,12\%, $74,12 \%, \quad 75,29 \%$, dan 74,12\%. Sehingga rerata aktivitas dosen berada pada kategori sangat tinggi. Persentase aktivitas mahasiswa dari pertemuan ke-1 sampai pertemuan ke-6 semakin lebih baik dengan rerata persentase berturut-turut adalah $67,06 \%$, $67,06 \%, 68,24 \%, 71,76 \%, 69,41 \%$, dan $71,76 \%$. Sehingga rerata persentase aktivitas mahasiswa berada pada kategori tinggi.

\section{Pembahasan}

Bahan ajar yang telah memenuhi kriteria bahan ajar yang valid, selanjutnya dilakukan uji coba pada skala kecil di kelas matematika ekonomi. Bahan ajar yang dikembangkan diujicobakan pada mahasiswa program studi akuntansi. Uji coba penggunaan bahan ajar ini bertujuan untuk melihat apakah bahan ajar yang dikembangkan dapat meningkatkan hasil belajar mahasiswa?.

Mahasiswa menunjukkan perhatian dan ketertarikan yang lebih dalam proses pembelajaran menggunakan bahan ajar yang dikembangkan, karena mahasiswa tidak harus membuat catatan dan mereka berlatih soal - soal yang terdapat pada modul. Selain itu, mahsiswa sangat antusias karena proses pembelajaran menggunakan software geogebra untuk mengecek 
grafik dari fungsi fungsi ekonomi dalam pemberian contoh dan penyelesaian soal. Dengan beragam fasiltas yang dimiliki, GeoGebra dapat dimanfaatkan sebagai media pembelajaran, mahasiswa dapat mendemonstrasikan atau memvisualisasikan grafik-grafik fungsi ekonomi serta sebagai alat bantu untuk mengecek kebenaran dari grafik yang mereka buat secara manual. Hal ini sesuai dengan pernyataan (Hohenwarter . Bila diamati paling tidak ada 3 kegunaan Geogebra, yaitu sebagai: (1) Media pembelajaran matematika; (2) Alat bantu membuat bahan ajar matematika : (3) Meyelesaikan soal matematika.

Mahasiswa melalui software GeoGebra mendapat pengalaman langsung dalam belajar, selain itu software GeoGebra mendukung kegiatan mengecek hasil kerja dan dapat memotivasi mahsiswa dalam belajar matematika ekonomi. Hal ini ditunjukkan berdasarkan data hasil observasi pembelajaran mahasiswa, presentase rata-rata aktivitas belajar mahasiswa dalam mengikuti perkuliahan matematika ekonomi menggunakan bahan ajar matematika ekonomi berbasis learning cycle berbantuan software GeoGebra termasuk kategori tinggi.

Data hasil tes belajar mahasiswa berupa hasil pretes dan postes yang diperoleh melalui pemberian tes hasil belajar dianalisis secara deskriptif dan juga dilakukan uji beda skor postes kelas eksperimen dan kelas kontrol. Secara deskriptif hasil pretes kedua kelas menunjukkan bahwa skor hasil belajar mahasiswa kedua kelas adalah sama yaitu memperoleh skor 5 dari skor maksimal 100, karena seluruh mahasiswa hanya menuliskan diketahui dan ditanyakan saja tanpa menggunakan simbol untuk setiap apa yang diketahui dan ditanyakan dari soal soal yang diberikan. Rerata postes hasil belajar mahasiswa kelas eksperimen yaitu 69,88 dengan skor minimal hasil belajar 50 dan skor maksimal hasil belajar 95. Sedangkan rerata postes hasil belajar mahasiswa kelas kontrol yaitu 63,59 dengan skor minimal hasil belajar 40 dan skor maksimal hasil belajar 90. Hal ini menunjukkan bahwa terjadi peningkatan rerata Menujukkan bahwa rerata hasil belajar mahasiswa yang pembelajaran menggunakan bahan ajar yang dikembangkan secara deskriptif lebih baik daripada rerata hasil belajar mahasiswa yang pembelajaran tidak menggunakan bahan ajar yang dikembangkan. Selanjutnya data hasil belajar mahasiswa diuji menggunakan uji gain ternormalisasi untuk melihat kriteria peningkatan yang dicapai. Secara umum berdasarkan rata-rata klasikal diperoleh nilai Normalitas gain (g) sebesar 0,46 yang berarti tafsiran peningkatan motivasi belajar matematis termasuk dalam kategori sedang.

Berdasarkan uji beda menggunakan uji gain ternormalisasi, bahan ajar matematika ekonomi berbasis learning cycle berbantuan software GeoGebra yang dikembangkan dapat meningkatkan motivasi belajar mahasiswa. Hasil hasil penelitian ini sesuai dengan hassil penelitian yang dilakukan oleh Dogan \& Icel (2010) bahwa penggunaan software GeoGebra dalam pembelajaran dapat meningkatkan motivasi belajar peserta didik. Hal 
senada, dikemukakan oleh Kusumah (2003) perangkat lunak pembelajaran mempunyai empat keunggulan, yaitu 1) Melatih siswa mengeksplorasi konsep, 2) Meningkatkan kemampuan bernalar, 3) Mendorong siswa berpikir sistematis, logis dan analitis dan 4) Meningkatkan minat siswa untuk belajar matematika.

Berdasarkan uji statistik terhadap nilai-nilai matematika ekonomi yang mahasiswa peroleh, dengan taraf signifikansi $5 \%$ maka diperoleh $Z_{\text {hitung }}=-2,252$ dan taraf signifikansi 0,024 maka $\mathrm{H}_{0}$ ditolak, artinya terdapat perbedaan yang signifikan antara skor postes hasil belajar mahasiswa kelas kontrol dan kelas eksperimen secara signifikan. Sehingga, terdapat perbedaan yang signifikan antara skor postes hasil belajar mahasiswa menggunakan bahan ajar matematika ekonomi berbasis learning cycle berbantuan GeoGebra dan yang tidak menggunakan bahan ajar matematika ekonomi berbasis learning cycle berbantuan GeoGebra. Dalam hal ini peningkatan hasil belajar mahasiswa yang menggunakan bahan ajar matematika ekonomi berbasis learning cycle berbantuan GeoGebra lebih baik dibandingkan mahasiswa yang pembelajarannya tidak menggunakan bahan ajar matematika ekonomi berbasis learning cycle berbantuan GeoGebra.

\section{KESIMPULAN DAN SARAN \\ Kesimpulan}

Kesimpulan yang diperoleh

berdasarkan penelitian pengembangan ini adalah:

1. Telah dikembangkan bahan ajar matematika ekonomi berbasis learning cycle berbantuan software GeoGebra melalui tiga tahap yaitu tahap pendahuluan, tahap pengembangan, dan tahap uji produk. Tahap pendahuluan meliputi analisis kebutuhan mahasiswa, dan analisis media/sumbar belajar. Tahap pengembangan meliputi mendesain bahan ajar matematika ekonomi berbasis learning cycle berbantuan software GeoGebra, tes hasil belajar, dan membuat lembar observasi belajar mahasiswa dan mengkonsultasikan bahan ajar yang telah didesain kepada validator dan melakukan uji coba terbatas, dan melakukan uji coba lapangan. Melalui langkahlangkah tersebut maka dihasilkan bahan ajar matematika ekonomi berbasis learning cycle berbantuan software GeoGebra.

2. Berkaitan dengan kualitas bahan ajar berdasarkan penilaian validator dan uji coba lapangan, dapat disimpulkan sebagai berikut.

a. Berdasarkan penilaian validator, bahan ajar matematika ekonomi berbasis learning cycle berbantuan software GeoGebra dalam kategori baik dengan presentase keidealan 77,96\%.

b. Berdasarkan uji coba lapangan, bahan ajar yang diekambangkan yaitu bahan ajar matematika ekonomi berbasis learning cycle berbantuan GeoGebra dapat meningkatkan hasil belajar mahasiswa.

3. Peningkatan hasil belajar mahasiswa yang menggunakan bahan ajar matematika ekonomi berbasis learning cycle berbantuan GeoGebra lebih baik dibandingkan mahasiswa yang 
pembelajarannya tidak menggunakan bahan ajar matematika ekonomi berbasis learning cycle berbantuan GeoGebra

\section{Saran}

Peneltian ini termasuk penelitian pengembangan bahan ajar yang memanfaatkan software untuk mengembangkannya. Adapun saran pemanfaatan dan pengembangan produl tindak lanjut adalah:

1. Saran Pemanfaatan

Peneliti menyarankan agar bahan ajar matematika ekonomi berbasis learning cycle berbantuan software GeoGebra yang dikembangkan:

a. Di ujicobakan kembali di beberapa kelas untuk mendapatkan hasil yang lebih beragam sehingga bahan ajar yang dikembangkan lebih baik lagi

b. Dimanfaatkan dalam pembelajaran mata kuliah matematika ekonomi

2. Saran Pengembangan Produk Lebih Lanjut

Bahan ajar matematika ekonomi berbasis learning cycle berbantuan geogebra yang telah dibuat dapat dikembangkan dan diperbaiki lebih lanjut untuk digunakan pada kegiatan penilitian selanjutnya.

\section{DAFTAR PUSTAKA}

Bybee, R. W., et al. (2006). The BSCS 5E Instructional Model: Origins, Effectiveness, and Applications. [Online]. Tersedia: http://www.bscs.org/pdf/bscs5ee xemummary.pdf. [12 Juni 2013].

Dimyati dan Mudjiono. (2009). Belajar dan Pembelajaran. Jakarta: Rineka Cipta.
Ergin, I. (2012). Constructivist Approach Based 5E model and Usability Instructional Physiscs. Lat. Am. J. Phys. Educ. Vol. 6, No. 1, 14-20.

Hajizah, M. N. (2014). Lentera Mahasiswa Kontribusi

Mahasiswa Pascasarjana dalan Meningkatkan Mutu Pendidikan, Budaya, dan Penelitian. Bandung: Alfabeta.

Hake, R. R. (1999). Analyzing Change/Gain Scores. Woodland Hills: Dept. of Physics, Indiana University. [Online]. Tersedia: http://www.physics.indiana.du/ sdi/AnaizyngChange-Gain.pdf [19 Maret 2013].

Hamalik, O. (2010). Proses Belajar mengajar. Jakarta: PT Bumi Aksara.

Lorsbach, A. W. (2002). The Learning Cycle as A tool for Planning Science Instruction. [Online]. Tersedia: (http://www.coe.ilstu.edu/scienc eed/lorsbach/257lrcy.html). [12 Juni 2013].

Madu, B. C., \& Amaechi, C. C., (2012). Effect of Five-Step Learning Cycle Model on Students' Understanding of Concepts Related to Elasticity. Journal of Education and Practice. Volume 3, No. 9, 2012.

[Online].

Tersedia:http://www.iiste.org/Jo urnals/index.php/JEP/article/vie wFile/2418/2434 [12 Juni 2013].

Sudjana, N. (2009). Penilaiaan hasil proses belajar mengajar. Bandung: PT Remaja Rosdakarya Offset.

Suprijono, A . 2010. Cooperative learning. yogyakarta : Pustaka pelajar. 
